\title{
Die retoriese analise van die Brief aan Filemon in die lig van Johannes Chrysostomus se homilieë oor dié brief
}

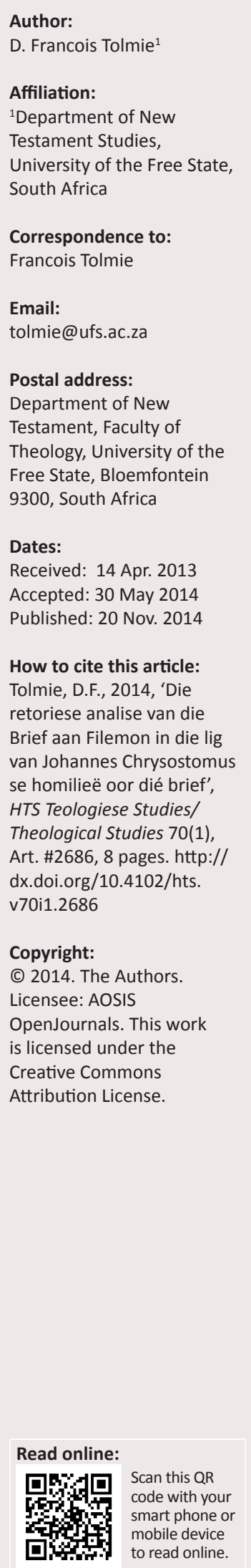

The rhetorical analysis of the Letter to Philemon in the light of John Chrysostom 's homilies about this letter. The study of Paul's Letter to Philemon benefitted from the renewed interest in the rhetorical analysis of New Testament writings in recent times, in the sense that a large number of rhetorical studies of the letter have been published. These rhetorical analyses of the letter have been done from various perspectives, but until now no one has systematically investigated the way in which John Chrysostom interpreted the letter rhetorically in his three 'Homilies on Philemon'. Accordingly, the study offers a detailed investigation of this issue. It is shown that John Chrysostom identified several important rhetorical aspects that have been neglected by modern scholars - aspects which could be used to enhance current interpretations of the rhetoric of the letter.

\section{Inleiding}

Die hernude belangstelling in die retoriese analise van die Nuwe Testament die afgelope paar dekades het ' $n$ positiewe effek op die navorsing oor Paulus se Brief aan Filemon gehad. Dit kan 'n mens veral sien uit die feit dat heelwat retoriese analises van dié brief reeds verskyn het. As 'n mens dié analises met mekaar vergelyk, is die verskil in aanslag nogal opvallend. Ek noem enkele studies om dit te illustreer: Forrester Church (1978:17-33) verkies die tradisionele benadering: die brief word as 'n voorbeeld van deliberatiewe retoriek geklassifiseer, en dan ingedeel volgens klassieke retoriese kategorieë (kyk ook na die latere studie van Kumitz 2004 wat dieselfde benadering volg, maar 'n ander indeling gebruik); Andrew Wilson (1992:107-19) volg 'n moderne benadering, die pragmatiek van Geoffrey Leech; Craig Wansink (1996:64-84) fokus weer op die verskillende maniere waarop Paulus homself in die brief beskryf en die bedoelde effek wat dit op Filemon moes gehad het; David Russell (1998:1-25) benader die brief as 'n vroeë Christelike versoekbrief ('appeals letter') en maak gebruik van 'n metodologiese raamwerk wat deur Richard Longacre geskep is; Scott Elliott (2011:51-64) fokus op die verskillende maniere waarop Paulus retoriese tegnieke van takt gebruik as deel van 'n magspel met Filemon; Andries Snyman (2009:178-193) maak gebruik van 'n teksgesentreerde retoriese benadering; Peter Lampe (2010:61-78) volg 'n retories-psigologiese benadering om die impak van emosies in die brief te beskryf, en Ernst Wendland (2010:79-112) konsentreer spesifiek op die retoriese funksie wat die styl van die brief het. Hierdie kort oorsig is nie volledig nie, maar tog genoeg om die wye reeks invalshoeke te illustreer van waaruit die retoriek van die brief al benader is.

Daar is egter een invalshoek waaraan, sover ek kon vasstel, nog nie reg geskied het nie en dit is om die brief te lees in die lig van die bydrae wat Johannes Chrysostomus (hierna JC) se homilieë oor die Brief aan Filemon (Hom. in Philm.) tot die verstaan van die retoriek van die brief sou kon lewer. Dit is wel so dat enkele van die navorsers wat hier bo genoem is, soms na Hom. in Philm. verwys, byvoorbeeld Church $(1978: 23,26)$ wat twee kursoriese verwysings daarna het, maar daar is nog geen volledige ondersoek gedoen na die manier waarop JC die retoriek van die brief aan Filemon verstaan het nie. Dit is verbasend, veral as 'n mens sy uitstekende retoriese opleiding in ag neem (sy leermeester was die bekende Libanius), asook sy eie uitstaande retoriese vermoëns ${ }^{1}$ wat hom die bynaam Goue Mond besorg het (Drobner 2008:327-328). Daar is wel al goeie studies oor Hom. in Philm. geskryf, ${ }^{2}$ byvoorbeeld die artikels wat in die debat tussen Mitchell en Callahan oor die ontstaan van die brief verskyn het (Callahan 1993:357-376, 1995:149-156; Mitchell 1995:135-148); asook die deeglike studie van die gebruik van die diskoers oor eer in Hom. in Philm. deur De Wet (2010:317-331). Nie een van hierdie studies fokus egter eksplisiet op die retoriese aspek van die Brief aan Filemon nie. Dit is wel waar dat JC homilieë oor die Brief aan Filemon geskryf het, en nie ' $n$ retoriese analise van die brief of selfs ' $n$ kommentaar daarop nie, en dat 'n mens in gedagte moet hou dat sy bedoeling in dié homilieë nie primêr was om die retoriek van die brief te beskryf 1.Kyk in Mitchell (2002:22-28) vir'n goeie oorsig van die navorsing wat reeds oor JC se retoriese vernuf gedoen is.

2.Die datering van die homilieë oor Filemon is onseker. Sommige kenners (Quasten 1960:448-449) dateer dit tydens JC se bediening in Antiochië (386-397 n.C.) en ander (Kelly 1995:132-133) tydens sy bediening in Konstantinopel (ongeveer 402 n.C.). Vir die doel van hierdie studie maak die datering van die homilieë nie werklik saak nie. 
nie. ${ }^{3}$ Tog is dit ook so dat JC talle opmerkings maak oor Paulus se bedoeling met die brief, asook die effek wat dit volgens hom op Filemon gehad het, en dat 'n mens daaruit 'n baie goeie beeld kan kry van die manier waarop hy die retoriek van die brief verstaan het. Dit is dus die oogmerk van hierdie artikel om Hom. in Philm. te ondersoek om te bepaal hoe JC die retoriek van die Brief aan Filemon begryp het, en vas te stel hoe bestaande retoriese benaderings tot die brief hierdeur verryk sou kon word.

\section{Retoriese aspekte in Johannes Chrysostomus se homilieë oor die Brief aan Filemon}

Soos reeds hierbo aangedui, toon Hom. in Philm. primêr 'n pastorale ingesteldheid en was dit nie JC se bedoeling om 'n retoriese analise van dié brief te skryf nie. Hy maak egter talle opmerkings oor die effek wat Paulus se brief op Filemon sou gehad het - veral in die eerste helfte van elkeen van die drie homilieë - en dit is waarop nou gefokus sal word. ${ }^{4}$ Die ondersoek begin by die inleidende gedeelte waarin JC die saak

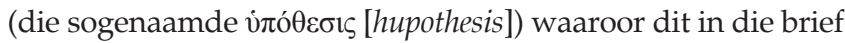
gaan, uiteensit, en beweeg daarna na die drie homilieë.

\section{Die saak waaroor dit in die Brief aan Filemon gaan}

JC begin sy bespreking met wat deesdae die 'retoriese situasie' genoem sal word, met ander woorde 'n beskrywing van die situasie waarbinne die poging tot oorreding gesitueer word. Dit is opvallend dat JC sy beskrywing hiervan begin met die stelling dat Filemon, die ontvanger van die brief, 'n eerbare man was. In sy eie woorde: 'Filemon

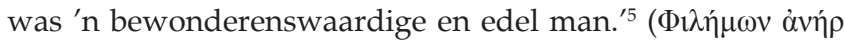

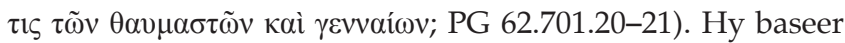
dié stelling op die volgende: die feit dat Filemon se hele huishouding gelowiges was, Filemon se gehoorsaamheid, dat Paulus in vers 7 daarna verwys dat die gelowiges se harte deur Filemon verkwik word, asook dat dit vir hom lyk asof Filemon dikwels verblyf aan gelowiges verskaf het - 'n afleiding wat hy maak uit Paulus se versoek in vers 22 dat Filemon vir hom verblyf gereed moet maak (PG 62.701.2130). Volgens JC het hierdie bewonderenswaardige man se slaaf Onesimus van sy goed gesteel en gevlug. Onesimus het toe by Paulus in die gevangenis in Rome uitgekom waar hy deur hom onderrig en gedoop is. Paulus skryf die brief hierna met die volgende doel: 'Daarom skryf Paulus en beveel hom aan by sy eienaar sodat hy hom vir alles sal vergewe en hom sal ontvang as iemand wat nou wedergebore is' ('O qoívvv

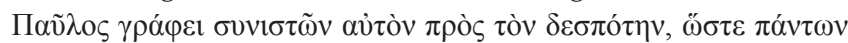

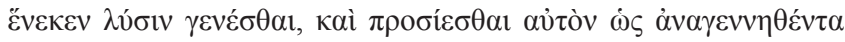
võv; PG 62.701.40-702.18.) In die gedeelte wat volg, verskuif JC se aandag na besware van sommige dat dié brief eintlik

3.Soos Decock (2010:273-288) tereg aantoon, het die klem in die vroeë kerk geval op die goddelike boodskap wat Bybeltekste vir die lesers gehad het. Dit was dan ook die bedoeling waarmee JC die Brief aan Filemon gelees en daaroor gepreek het.

4.Die Griekse teks is beskikbaar in PG 62.701-720. Vir die doeleindes van hierdie artikel is die elektroniese weergawe van die Thesaurus Linguae Graecae gebruik (http://www.tlg.uci.edu/).

5.Alle vertaling uit Grieks deur myself; ek probeer in die vertaling van die Griekse teks so na as moontlik aan die bronteks bly. oorbodig is en probeer hy aantoon hoe bruikbaar dit wel vir gelowiges is - 'n gedeelte wat vir die doeleindes van hierdie artikel nie ter sake is nie. Daar kom egter wel twee opmerkings voor wat uitgelig moet word omdat dit verder lig werp op die manier waarop JC die retoriese situasie verstaan. Wanneer JC oor die bruikbaarheid van die brief skryf en wat gelowiges daaruit kan leer, noem hy twee begrippe waarop ons moet let: Hy wys daarop dat Paulus nie geweier het of hom geskaam ${ }^{6}$ het om Onesimus terug te stuur nie (PG 62.703.16-17). Daaruit kan 'n mens aflei dat JC die retoriese situasie opgesom het in terme van die belangrike rol wat die waardes van eer teenoor skande destyds gespeel het. Verder aan in hierdie oorsig sal ons sien hoe sleutelbegrippe binne die waardesisteem van eer en skande telkens deur JC gebruik word om Paulus se retoriese strategie te beskryf. Tweedens, JC beskryf die verandering wat in Onesimus plaasgevind het, en wat hy vroeër as 'hy is wedergebore' beskryf het, nou in terme van deugsaamheid - eweneens ' $n$ belangrike sosiale waarde in die destydse samelewing: 'Want as die dief, die

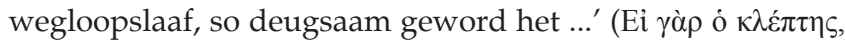

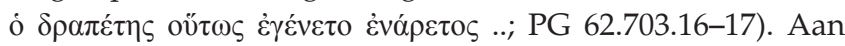
die einde van hierdie afdeling word hierdie twee gedagtes - beskaming en deugdelikheid - weer beklemtoon: 'Hy (d.i. Paulus) leer ons om nie skaam te wees vir ons slawe as hulle

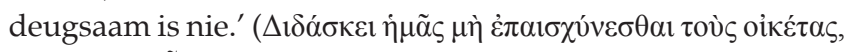

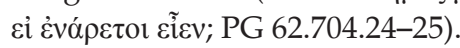

Om saam te vat: JC verstaan die retoriese situasie van die Brief aan Filemon soos volg: Paulus probeer 'n bewonderenswaardige en edel man oorreed om sy wegloopslaaf te vergewe en weer te ontvang omdat die slaaf ná sy doop herbore is en deugsaam geword het.

\section{Homilie 1 (Fil 1-3)}

In die eerste homilie behandel JC Filemon 1-3. Ek gee telkens 'n Afrikaanse vertaling van die Griekse teks soos dit deur JC aangehaal word. ${ }^{7}$

Vers 1-3:

Paulus, 'n gevangene van Christus Jesus, en Timoteus, die broer, aan Filemon, ons geliefde en medewerker, en aan geliefde Apfia, en aan Argippus, ons medestryder, en aan die kerk in jou huis: Genade vir julle en vrede van God, ons Vader, en van die Here Jesus Christus!

JC begin sy verduideliking met die stelling dat hierdie woorde aan 'n eienaar gerig word, namens 'n slaaf (PG 62.703.43). Hy beskryf die effek van hierdie verse op verskillende maniere: Paulus kalmeer Filemon se gemoed; verhoed dat hy beskaam word, en blus sy woede. Verder, deur homself 'n gevangene te noem, beweeg hy Filemon tot 'n skuldgevoel, sorg hy dat Filemon sy selfbeheersing terugkry en sal besef dat bestaande

6.Die term wat JC gebruik, is aioxvivopal (aischunomai; PG 62.703.17) - een van die Griekse standaardterme wat vir 'skande' binne die destydse waardesisteem van eer en skande gebruik is. Kyk Domeris (1993:284).

7.Soos vroeër aangedui, probeer ek telkens in my vertaling so naby as moontlik aan die bronteks bly. Waar daar opvallende verskille is tussen die Griekse teks wat JC gebruik het en dié van Nestle-Aland 28 (hierna NA28) word dit in voetnote aangedui.

8.Die Griekse teks wat JC gebruik het, het die woord 'geliefde' en nie 'suster' soos NA28 nie. 
dinge eintlik nie belangrik is nie. Filemon sal begryp dat as kettings ter wille van Christus iets is waarop ' $n$ mens trots is en nie skaam nie, is slawerny nog des te minder iets skandaligs. Volgens JC noem Paulus homself nie 'n slaaf met die doel om hom te verhef nie, maar wel om te wys dat hy 'n guns waardig is, en die guns dus op dié manier makliker te kan kry (PG 62.703.43-51). Dat Paulus homself "n gevangene van die Here noem', sou 'n kragtige effek op Filemon gehad het: dit sou by hom respek afgedwing het. Volgens JC sou enigiemand wat so iets lees, bereid wees om sy eie lewe op te offer, wat nog te sê van een enkele slaaf op te offer! (PG 62.704.37-38).

Dat Paulus Timoteus vermeld, word deur JC geïnterpreteer as 'n manier waardeur Paulus seker maak dat Filemon die guns wat hy vra, makliker gaan toestaan, aangesien die versoek nie net deur Paulus gerig word nie (PG 62.704.4041). Ook die maniere waarop Filemon beskryf word, word deur JC beskou as 'n strategie om Filemon te oortuig: dat hy 'n 'geliefde' van Paulus is, toon dat dit wat Paulus vra, nie te ver gaan nie, maar dat dit ' $n$ teken van sy groot liefde is; dat Filemon Paulus se 'medewerker' is, wys nie net dat Filemon so 'n versoek waardig is nie, maar ook dat hy voldoening aan Paulus se versoek eintlik as ' $n$ guns behoort te beskou: hy bou immers aan dieselfde werk as Paulus en deur hierdie guns vir hom te doen, bewys hy dus eintlik ook 'n guns aan homself (PG 62.704.42-47).

Dat Paulus ook vir Apfia (wat JC as Filemon se eggenote verstaan) en Argippus (volgens JC, moontlik 'n vriend) in sy brief noem, lees JC as 'n manier wat groter impak verseker: as die versoek aan meer mense gerig word, is daar ' $n$ groter kans dat dit sal slaag. Volgens JC noem Paulus doelbewus vir Argippus 'n 'medestryder': As hy Paulus se medestryder is, sal hy ook in hierdie saak saam met Paulus werk.

Paulus se woorde 'en aan die kerk in jou huis' word deur Filemon op 'n interessante manier verstaan. Vir JC was die huiskerke waarvan in die Nuwe Testament gepraat word, 'n onbekende verskynsel, en hy interpreteer die uitdrukking dus konsekwent as ' $n$ aanduiding dat almal in ' $n$ bepaalde huis Christene was, en nie as 'n verwysing na 'n groter, meer verteenwoordigende groep mense wat in ' $n$ bepaalde huis bymekaar gekom het nie (Mitchell 1995:138). In hierdie geval verstaan hy Paulus se verwysing na die kerk in Filemon se huis dus as ' $n$ aanduiding dat almal in Filemon se huis Christene was, en vestig hy die aandag spesifiek daarop dat dié beskrywing ook die slawe in die huis ingesluit het. Hy interpreteer dit as 'n baie effektiewe strategie: Paulus het geweet dat slawe se woorde 'n groot impak op hulle eienaar kon hê, veral omdat dit in hierdie geval oor 'n medeslaaf gegaan het. Hy doen dit egter op 'n baie slim manier: Deur implisiet na hulle te verwys, en hulle by die aanhef van die brief by hulle eienaar ${ }^{9}$ in te sluit, eer (let op dat hierdie begrip nou weer opduik) hy hulle en verhoed hy dat hulle afgunstig op Onesimus word. Aan die ander kant noem Paulus hulle

9.0p hierdie punt het die Griekse teks letterlik 'eienaars' (meervoud); verder aan in hierdie gedeelte word egter deurgaans van die eienaar (dit is Filemon) in die enkelvoud gepraat, en ek gebruik dus ook hier liewer die enkelvoud. egter nie eksplisiet nie, want dit sou dalk vir Filemon kon aanstoot gee. Paulus gaan dus op 'n baie vernuftige manier te werk: 'deur sowel hulle [d.i. die slawe] te eer deur hulle vermelding, en hom [Filemon] nie seer te maak nie.' (PG

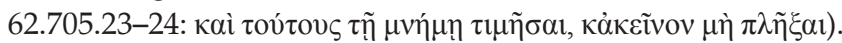

Selfs die woorde 'genade en vrede' word direk deur JC op die retoriese situasie betrek: Deur 'genade' te noem, word Filemon herinner aan sy eie sonde en hoeveel God hom vergewe het; dat hy deur genade gered is. Die oproep wat nou tot Filemon gerig word, is: 'Volg die voorbeeld van jou Eienaar!' ( $\mu$ í

\section{Homilie 2 (Fil 4-16)}

Verse 4-6:

Ek dank my God altyd wanneer ek van jou melding maak in my gebede omdat ek hoor van jou liefde en van die geloof wat jy het vir die Here Jesus en vir al die heiliges, sodat die gemeenskap van jou geloof effektief mag word deur 'n insig van alles goeds wat in ons is, met die oog op Christus Jesus. ${ }^{10}$

JC begin eers met ' $n$ algemene opmerking wat betrekking het op 'n groter gedeelte as net verse 4-6. Hy wys daarop dat Paulus in hierdie deel van die brief nie onmiddellik oorgaan tot die rig van die versoek nie, maar eers 'n hele klompie ander dinge doen: Hy verwoord sy bewondering vir Filemon, prys hom vir sy goeie dade en die tekens van sy liefde, noem dat hy vir hom bid; dat die gelowiges se harte deur hom verkwik word, en vermeld Filemon se gehoorsaamheid. Eers daarna rig hy sy versoek. Volgens JC oorreed Paulus hier vir Filemon deur hom verleë te laat voel, ${ }^{11}$ want as Filemon bereid was om soveel vir andere te doen, is Paulus nog des te meer geregtig daarop dat Filemon iets vir hóm doen. JC gee ook 'n verdere rede waarom Paulus nie dadelik sy versoek rig nie. Paulus wou nie hê die indruk moes geskep word dat Onesimus die enigste rede was waarom hy die brief skryf nie; daarom skep hy ook ander redes vir die skryf van die brief, naamlik om sy liefde teenoor Filemon duidelik te maak en te vra dat 'n gastekamer vir hom gereed gemaak word (PG 62.707.40-708.44)

Wat verse 4-6 spesifiek betref, maak JC nog een verdere opmerking wat vir ons doeleindes belangrik is. Hy interpreteer die frase 'sodat die gemeenskap van jou geloof effektief mag word deur ' $n$ insig van alles goeds wat in ons is' alreeds as ' $n$ implisiete versoek aan Filemon. Die volgende drie aspekte moet verder uitgelig word: Eerstens volg hierdie implisiete versoek van Paulus (in JC se woorde, dat Paulus 'vra') op die voorafgaande waarin hy Filemon geprys het (in JC se woorde, dat Paulus 'gee'): met ander woorde Paulus 'gee' eers en dan 'vra' hy. Die tweede aspek is dat JC die (implisiete) versoek wat Paulus hier rig, opsom as 'n aansporing tot deugdelikheid: 'sodat hy alle deugdelikheid

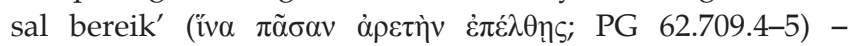
waardeur JC Paulus se retoriese strategie weereens verstaan in terme van belangrike waardes in die antieke wêreld.

10.NA28 lees net 'Christus'

11.My vertaling van $\alpha$ $\tau o ̀ v ~ \delta v \sigma \omega \pi \tilde{v ~(' h y ~ m a a k ~ h o m ~ v e r l e e ̈ ’ ; ~ P G ~ 62.707 .53) . ~}$ 
Derdens vestig JC die aandag op die uitdrukking 'gemeenskap van geloof': Paulus praat nie net van Filemon se geloof wat effektief moet word nie, maar spesifiek van die gemeenskap van sy geloof. Volgens JC verbind die woord 'gemeenskap' Filemon aan Paulus, en illustreer dit dat hulle een liggaam is, en dit maak Filemon des te meer verleë. Volgens JC is die onderliggende argument hier: 'As jy 'n deelgenoot is - sê hy in die geloof, dan is jy ook verplig om te deel wat ander dinge

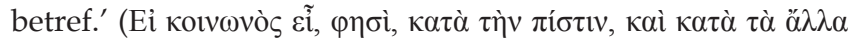

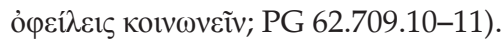

Vers 7: 'Want ons ${ }^{12}$ het vreugde en baie troos ${ }^{13}$ oor jou liefde gehad omdat die harte van die gelowiges deur jou verkwik is, broer!' In JC se verduideliking van hierdie gedeelte is daar twee aspekte wat vir ons ondersoek belangrik is. Eerstens lees hy hierdie vers ook as 'n insinuasie (die

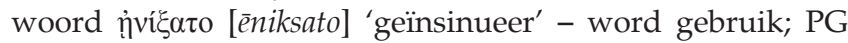
62.709.18) dat Filemon Paulus moet help. Sy argument loop as volg: Niks maak iemand meer verleë om iemand anders te help as wanneer hulle herinner word aan hulle goedheid teenoor andere nie, veral nie as daardie persoon 'meer eerbiedwaardig' is as die mense wat hy reeds gehelp het nie. Die woord wat JC hier vir 'meer eerbiedwaardig' gebruik, is

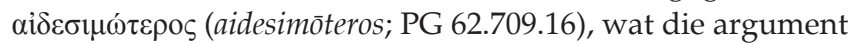
dus ook binne die diskoers oor eer en skande in die antieke plaas: Omdat Paulus meer eerbiedwaardig is as die mense vir wie Filemon reeds gehelp het, is Filemon verplig om hom ook te help. Verder gebruik JC weer die gedagte dat die kerk een liggaam is om Paulus se argument te verduidelik: Omdat gelowiges een liggaam is, is Paulus bly daaroor dat ander gelowiges se harte deur Filemon verkwik is. Ook dié gedagte word deur JC as 'n aansporing van Paulus se kant af aan Filemon gelees: Indien Filemon ook Paulus se gevoelens verkwik, sal hy Paulus se blydskap des te groter maak (PG 62.709.20-32).

Vers 8: 'Daarom, al het ek in Christus baie vrymoedigheid om jou te beveel wat gepas is ... .' In hierdie geval fokus JC op die manier waarop Paulus die moontlike skade wat die woord 'beveel' sou kon hê, beperk. Volgens JC kon die gebruik van dié woord dalk Filemon se gevoelens seermaak. Daarom begin Paulus met 'n verwysing na die vrymoedigheid wat hy het om Filemon te nader; volgens JC impliseer dit dat Filemon 'n 'groot man' is, want dit beteken dat Filemon se vroeëre optrede Paulus soveel meer vrymoedig teenoor hom gemaak het. Verder gebruik Paulus doelbewus die uitdrukking 'in Christus' om aan te dui dat Filemon se grootheid nie ' $n$ wêreldse soort grootheid is nie, maar dat dit gaan oor sy geloof in Christus. Eers dán gebruik Paulus die woord 'beveel'. Paulus voeg egter dadelik weer die woorde 'wat gepas is' by, waardeur hy wil aandui dat sy versoek 'n redelike versoek is. JC vat dit alles saam deur te wys op al die boustene wat hier in Paulus se argument gebruik word: Filemon doen goed aan ander; hy doen goed aan Paulus; hy doen dit ter wille van Christus; dit wat Paulus van hom vra, is redelik; en liefde maak 'n mens vrygewig (PG 62.709.3350). Met die begrip 'liefde' maak JC dan die oorgang na die

12.NA28 lees 'ek ... het gehad' in plaas van JC se 'ons het'.

13.NA28 lees 'baie vreugde en troos' in plaas van JC se 'vreugde en baie troos'. eerste gedeelte van vers 9a: '... pleit ek liewer ter wille van die liefde ... .'

Die feit dat Paulus beide beveel en pleit word deur JC as volg geïnterpreteer: Hy beveel Filemon, want hy het vrymoedigheid teenoor hom, maar hy pleit ook, wat wys hoe belangrik hierdie saak vir hom is (PG 62.709.50-55).

Vers 9b: '... ek, Paulus, 'n ou man ... 'n gevangene van Jesus Christus; ... . ${ }^{\prime 14} \mathrm{JC}$ interpreteer hierdie frase as 'n verdere manier waardeur Filemon deur Paulus verleë gemaak word sodat hy sal doen wat Paulus van hom verwag. JC lees die frase as drie aparte sake wat deur Paulus gebruik word om Filemon verleë te maak: Eerstens, die kwaliteit van Paulus se persoon; tweedens, Paulus se ouderdom; en derdens, die feit dat hy 'n gevangene van Jesus Christus is. JC evalueer hierdie poging van Paulus as baie effektief: wie sal so iemand nie graag ontvang nie - soos wat 'n mens 'n atleet wat bekroon is met oop arms ontvang nie? En: Wie sal nie bereid wees om hom 10000 gunste te bewys omdat hy 'n gevangene ter wille van Christus is nie? (PG 62.709.58$710.2)$.

Vers 10: 'Ek smeek jou ten opsigte van my kind, wat ek in die boeie verwek het, Onesimus ... .' JC wys daarop dat Paulus nou eers eksplisiet by sy versoek uitkom. Tot dusver was hy nog net besig om Filemon se gemoed te kalmeer - wat te verstane is omdat almal weet hoe eienaars voel teenoor slawe wat gedros het, en veral nog as hulle gesteel het. Selfs goeie eienaars se woede neem in so 'n geval toe. Volgens JC het Paulus in hierdie stadium reeds die volgende reggekry: hy het Filemon gekalmeer, hom oorreed om hom behulpsaam te wees, en hom op gehoorsaamheid voorberei. Nou eers volg die versoek. JC wys verder op die vernuftige wyse waarop Paulus die versoek formuleer. Hy weerhou Onesimus se naam tot heel laaste. Hy gebruik eers die woorde 'my kind wat ek in boeie verwek het', en eers daarna volg Onesimus se naam. JC beklemtoon dan twee aspekte. Hy laat val eerstens die klem op die statusverandering wat Onesimus ondergaan het. Hy is nou Paulus se 'seun'. JC noem dit 'lofprysing': Paulus sou hom nie 'seun' genoem het as hy nie gedink het hy is 'uiters bruikbaar' nie. JC se gevolgtrekking: Die feit dat hy Paulus se 'kind' is en dat hy juis 'verwek' is toe Paulus in die gevangenis was, beteken dat hy 'verwek' is terwyl Paulus vir Christus gely het. Die tweede aspek wat JC uitlig, is Paulus se gebruik van die begrip 'boeie'. Hy beskou dit as 'n tegniek waardeur Filemon verleë gemaak word sodat hy sal doen wat Paulus verwag. Verder interpreteer hy dit ook as 'n manier waarop Paulus Onesimus se statusverandering verder beklemtoon. Die feit dat Onesimus juis 'verwek' is tydens Paulus se gevangenskap, met ander woorde terwyl Paulus vir die saak van Christus gely het, verleen ook eer aan Onesimus (PG 62.710.12-22.) Anders gestel: Die omstandighede van Onesimus se 'verwekking' maak van hom 'n eerbare mens. In JC se eie woorde: 'Sodat hy ook as gevolg hiervan waardig was om baie eer te beurt te val.'

14.JC haal net twee gedeeltes van hierdie frase aan; hy laat die woorde 'en nou ook (vvvì $\delta \dot{\varepsilon}$ Kaí) uit. Verder is die woorde 'Christus Jesus' in die teks wat hy gebruik, omgeruil. 


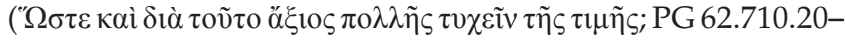
21). Soos De Wet (2010:325) tereg uitwys, fokus JC hier op die nuut geskepte fiktiewe verwantskap ('newly found fictive kinship') tussen Paulus en Onesimus, wat gebruik word om Onesimus binne die eerbaar voor te stel.

Vers 11: '... Onesimus, wat eens vir jou onbruikbaar was, maar nou ook vir jou en vir my bruikbaar ${ }^{15}$ sal wees ... .' In sy verduideliking van hierdie vers beklemtoon JC Paulus se insig: dat hy Onesimus se sondes bely en so Filemon se woede stil. Volgens JC verwys Paulus ook doelbewus na Onesimus se bruikbaarheid vir beide Paulus en Filemon, en nie net vir Filemon nie, aangesien laasgenoemde dalk deur Filemon weerspreek sou kon word. Paulus verbind Onesimus ook aan homself, dit wil sê aan sy eie persoon, om so sy stelling meer geloofwaardig te maak. JC se gevolgtrekking: As Onesimus bruikbaar was vir Paulus - wat soveel presiesheid ${ }^{16}$ ten opsigte van deugdelikheid verwag het - hoeveel te meer sou hy nie bruikbaar vir Filemon kon wees nie (PG 62.710.23-32).

Vers 12: '... hom wat ek aan jou stuur. Jy moet hom - my hart se punt ${ }^{17}$ - ontvang; ... . ${ }^{\prime 18}$ Volgens JC sou hierdie stelling Filemon se woede gestil het, want eienaars is gewoonlik woedend wanneer hulle versoeke ontvang oor slawe wat afwesig is. Hy wys verder daarop dat Filemon nie Onesimus se naam noem nie, maar die woord 'hart se punt' gebruik 'n woord wat' $n$ beskamende effek op Filemon sou hê en wat nog meer intens is as die woord 'seun' (wat vroeër gebruik is). Volgens JC was die rede vir Paulus se besondere liefde vir Onesimus die feit dat hy 'verwek' is tydens Paulus se swaarkry, want mense voel van nature meer vir kinders wat in 'n gevaarsituasie gebore is (PG 62.710.32-44).

JC wys verder op die manier waarop Paulus sy versoek verwoord. Paulus vra nie dat Filemon vir Onesimus moet terugvat of nié vir hom kwaad moet wees nie. Hy vra spesifiek dat Filemon hom moet 'ontvang'. Uit die manier waarop JC die woord 'ontvang' hier interpreteer, kan 'n mens agterkom dat hy 'n spesifieke nuanse in die gebruik van die woord raaklees, een wat deur Lampe (1961: $\pi \rho \circ \sigma \lambda \alpha \mu \beta \alpha ́ v \omega)$ saamgevat word as 'receive, accept someone ... of hospitality among men' (beklemtoning in Lampe). JC se volgende opmerking toon ook hoekom hy dit so interpreteer, want daaruit kan 'n mens sien hy beskou dit binne die waardesisteem oor eer en skande: 'Hy (d.i. Onesimus) is nie net kwytskelding waardig nie, maar ook eer. Hoekom? Want hy het Paulus se seun

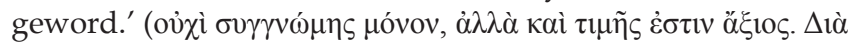

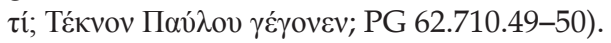

Vers 13:' ... hom wat ek in jou plek wou hou sodat hy my, in die boeie van die evangelie, kon dien ... . ${ }^{\prime 19}$ Uit hierdie vers maak

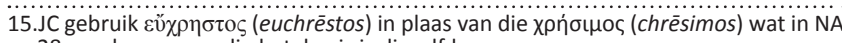
28 voorkom, maar die betekenis is dieselfde.

16.Die woord wat JC gebruik, is ákpíßsı (akribeia; PG 62.710.31) en moet hier verstaan word as 'scrupulousness, exact conformity with virtue' (Lampe 1961:64; beklemtoning in Lampe).

17.Elders in hierdie artikel het ek telkens $\sigma \pi \lambda \alpha \dot{\gamma} \gamma \nu \alpha \alpha$ (splagchna) met 'hart' vertaal; in hierdie geval gebruik ek die Afrikaanse uitdrukking 'hart se punt' omdat dit die gevoelswaarde hier goed raakvat.

18.In NA28 is vers 12 een sin; die teks wat JC gebruik toon dit as twee sinne, en het ook'n ekstra werkwoord ('ontvang'; vgl. v. 17 in NA28).

19.Die volgorde van die woorde in die teks wat deur JC gebruik is, verskil op verskeie
JC afleidings ten opsigte van beide Onesimus en Filemon. Wat Onesimus betref, fokus hy weereens op die begrip 'eer': Die woorde in hierdie vers toon hoe Paulus Onesimus op 'n eervolle manier voor sy eienaar bring. Wat Filemon betref, beklemtoon JC dit wat hy aan Paulus verskuldig is: Hy behoort vir Paulus te dien, en hier is daar nou 'n manier om dié diens te lewer. Op dié manier wys Paulus dat dit eintlik vir hom meer gaan oor die voordeel wat Filemon gaan trek as dat Onesimus daarby sou baat vind (PG 62.710.51-59).

Vers 14: '... maar sonder jou medewete wou ek niks doen nie, sodat jou goedheid nie op grond van dwang sou wees nie, maar op grond van vrywilligheid.' Om iemand te vra om mee te werk aan 'n verdienstelike saak, is volgens JC 'n manier om iemand 'sag te maak' ( $\chi \alpha v v o ́ \omega ~[c h a u n o \overline{]}$; PG 62.710.62), en dit is wat Paulus hier doen. Dit het 'n tweërlei effek: Paulus baat daarby, want daar sal aan sy versoek voldoen word; en Filemon voel geborge, want sy betrokkenheid by die saak word beklemtoon (PG 62.710.59-711.1). Verse 15-16:

Want, miskien ter wille hiervan is hy vir 'n ruk van jou geskei sodat jy hom vir ewig ten volle mag hê, nie langer as 'n slaaf nie, maar méér as 'n slaaf, as 'n geliefde broer - veral vir my. ${ }^{20}$

JC wys daarop dat die woord ró $\chi \alpha$ ['miskien'] 'n goeie keuse is, want Onesimus se vlug is deur sy moedswilligheid en verdraaide denke veroorsaak. Verder wys hy ook op Paulus se woordkeuse: Hy sê nie dat Onesimus gevlug het of hom van Filemon geskei het nie, maar sê dat hy van Filemon 'geskei is'. Soos wat in die geval van Josef gebeur het (Gen 45:5), het God dus Onesimus se boosheid vir 'n goeie doel aangewend. Verder beklemtoon Paulus dat dit net vir 'n kort tydjie was. JC vat Paulus se strategie soos volg saam: 'En hy verkort die tyd, bely die oortreding, en verander alles

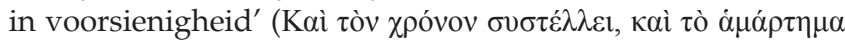

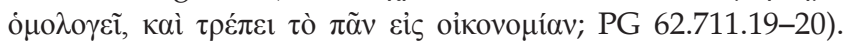
Wat die res van die vers betref, lig JC uit dat Filemon volgens Paulus op verskeie maniere by die situasie baat: Onesimus sal vir altyd Filemon se slaaf bly; hy sal inderwaarheid meer eerbaar as 'n slaaf wees, want hy sal Filemon goedgesind wees (selfs meer goedgesind as wat 'n broer sou wees!), en hy sal nooit weer vlug nie. Filemon baat dus op twee maniere: sowel in terme van tyd as in die kwaliteit van sy slaaf. Oor die begrip 'geliefde broer' wat deur Paulus gebruik

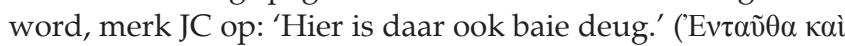

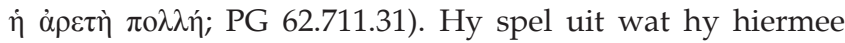
bedoel deur weereens gebruik te maak van kategorieë van eer en skande: Onesimus is Paulus se 'broer' en daarom hoef Filemon hom nie vir Onesimus te skaam nie. JC bring dit ook in verband met Paulus se vroeëre verwysing na Onesimus as sy 'seun': Toe Paulus vir Onesimus 'seun' noem, het hy die natuurlike liefde wat ouers teenoor kinders het, teenoor Onesimus getoon; deur hom nou 'broer' te noem, toon hy sy goedgesindheid teenoor Onesimus en wys hy dat Onesimus gelykwaardig in eer ${ }^{21}$ aan hom is (PG 62.711.15-35).

(Footnote 19 continues ...)

plekke van NA28, maar daar is nie 'n groot verskil in betekenis nie.

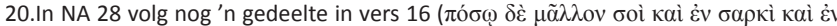
кupí $\omega$; 'en hoeveel te meer vir jou, in die vlees én in die Here').

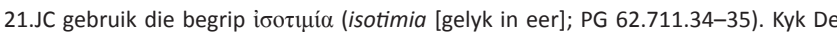
Wet (2010:325-326) vir 'n goeie bespreking van die wyse waarop JC hierdie idee van toepassing maak op sy eie tyd, en die houding wat eienaars teenoor hulle slawe behoort te hê. 


\section{Homilie 3 (Fil 17-25)}

Verse 17-19:

As jy my dan as 'n deelgenoot beskou, ontvang hom soos vir my. En as hy jou in iets te na gekom het of iets skuld, sit dit vir my op rekening. Ek, Paulus, skryf dit met my eie hand: ék sal betaal, om nie aan jou te noem dat jy ook jouself aan my verskuldig is nie.

Ten opsigte van Paulus se versoek 'ontvang hom soos vir my', maak JC twee opmerkings: Eerstens wys hy op Paulus se strategie om nie alles op een slag te vra nie, 'n strategie wat volgens JC baie effektief is. Paulus het Filemon vooraf stukkie vir stukkie voorberei: Eers het hy Onesimus sy 'seun' genoem; toe gemeld dat hy deelgenoot van die evangelie is; daarna dat hy Paulus se 'hart se punt' is; en nog later gevra dat Filemon hom as 'n 'broer' moet ontvang. Ná al hierdie voorbereiding kom die versoek dan by: 'Ontvang hom soos myself.' Tweedens beklemtoon JC weereens die feit dat Paulus die versoek rig sonder om hom daaroor te skaam (weer die terminologie van eer teenoor skande): Hy het hom nie geskaam om 'n slaaf van die gelowiges genoem te word nie en dit is vir hom nog minder van 'n probleem om Onesimus aan homself gelyk te stel (PG 62.713.53-61).

Wat Paulus se opmerking betref dat enige skade wat Onesimus aan Filemon berokken het, op Paulus se rekening geplaas kan word, wys JC daarop dat Paulus die moontlike skade nóu eers noem, nadat hy reeds intens voorspraak vir Onesimus gedoen het. Die rede hiervoor is dat geldelike verlies mense baie kwaad maak en Onesimus waarskynlik die geld reeds uitgegee het. JC wys ook daarop dat Paulus die woord 'steel' vermy, maar die sagter uitdrukking 'te na kom', kies. Paulus kry dit dus reg om Onesimus se oortreding te bely, maar terselfdertyd die perspektief te verskuif: dit is nie die oortreding van ' $n$ slaaf teenoor ' $n$ eienaar nie, maar van ' $n$ vriend teenoor ' $n$ vriend (PG 62.714.49-59).

Volgens JC word Paulus se onderneming dat hy Filemon sal terugbetaal 'met ' $n$ gees van welwillendheid' ${ }^{22}$ gedoen. Dit is tegelyk roerend en welwillend: As Paulus nie weier om op hierdie manier vir Onesimus in te staan nie, kan Filemon ook nie weier om vir Onesimus te ontvang nie. Volgens JC kry Paulus hiermee tegelyk twee dinge reg: hy maak vir Filemon verleë en kry vir Onesimus uit die moeilikheid. Dit is verder ook'n pragtige aanduiding van hoeveel Paulus vir Onesimus omgee (PG 62.715.1-9).

JC interpreteer Paulus se woorde 'om nie aan jou te noem dat jy ook jouself aan my verskuldig is nie' op 'n interessante manier. Volgens hom gebruik Paulus dit om te keer dat Filemon beledig voel deurdat dit miskien kan lyk asof Paulus nie genoeg vertroue in die verhouding tussen hom en Filemon het om 'n versoek oor die diefstal van Onesimus te rig nie. Paulus se woorde funksioneer dus versagtend. Soos JC Paulus se strategie hier interpreteer: 'En dit was gebaseer op liefde, en was volgens die saak van vriendskap,

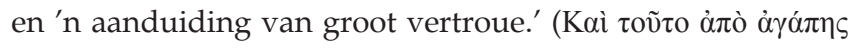

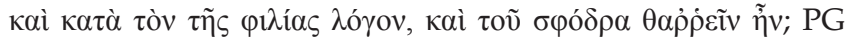
62.715.16-17).

Vers 20: 'Ja, broer, mag ék van jou baat vind in die Here; verkwik my gevoelens in Christus!' JC interpreteer Paulus se 'Ja, broer' as 'n implisiete versoek aan Filemon om Onesimus te ontvang. Volgens JC is die gemoedelikheid ${ }^{23}$ verby en fokus Paulus nou weer op belangrike sake. Die woorde 'in die Here' in Paulus se pleidooi word deur JC verstaan as dat Filemon eintlik die guns aan die Here bewys en nie aan Paulus nie, en die woord 'hart' in 'verkwik my hart' as 'n verwysing na Filemon self, oftewel na Paulus se gevoelens vir Filemon (PG 62.715.20-29).

Vers 21: 'Oortuig van jou gehoorsaamheid, skryf ek aan jou omdat ek weet dat jy ook meer as dit wat ek vra, sal doen.' JC beklemtoon die effek wat hierdie woorde op Filemon sou hê; dit sou selfs 'n klip kon sag maak! Hy wys ook daarop dat Paulus met die uitspreek van sy vertroue, weer teruggryp na die manier waarop hy sy versoek begin het (v. 8). Ten opsigte van Paulus se opmerking dat Filemon meer sal doen as wat hy vra, brei JC nie uit op presies wat Paulus daarmee bedoel nie. Hy sê bloot dat dit 'n manier is om Filemon aan te spoor, en dat hierdie opmerking alleen genoeg sou wees om Filemon te beskaam om te doen wat Paulus vra (PG 62.715.21-42).

Vers 22: 'En maak ook terselfdertyd vir my 'n gastekamer gereed, want ek hoop dat ek deur julle gebede aan julle geskenk sal word.' JC lees hierdie woorde van Paulus ook as 'n manier om Filemon aan te spoor om te doen wat van hom verwag word, want hy sou besef dat wanneer Paulus hom besoek, hy sal uitvind hoe Filemon op sy brief gereageer het. JC beklemtoon verder die groot eer wat dit vir Filemon sou wees om Paulus te huisves (PG 62.715.42-54).

In sy bespreking van die laaste drie verse - die slotgedeelte van die brief - maak JC net twee opmerkings wat belangrik is vir die verstaan van die retoriek van die brief. Eerstens wys hy daarop dat Paulus na Epafras, sy 'medegevangene', verwys, wat ook uit Kolosse afkomstig is. Volgens JC is Paulus se bedoeling om daarmee nog druk op Filemon te plaas: As Epafras as Filemon se mede-inwoner van Kolosse saam met Paulus ly en Filemon self nie kans sien om vir Paulus 'n guns te doen ten opsigte van sy slaaf nie, sou hy beskaamd gestaan het (PG 62.716.1-4). Tweedens wys hy daarop dat Paulus die mense wat hy in vers 24 vermeld, 'medewerkers' noem - nog 'n manier om Filemon te 'beskaam' om aan sy versoek te voldoen (PG 62.716.20-22).

\section{Evaluering}

In die lig van die voorafgaande oorsig is die belangrike vraag wat nou gestel moet word of JC se interpretasie van die Brief aan Filemon enigsins van hulp kan wees in die retoriese analise van die brief. Myns insiens is dit beslis die geval. Ek lig drie belangrike aspekte uit:

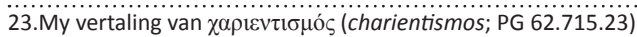


Eerstens, wanneer 'n mens die oorkoepelende benadering, wat deur JC gevolg word, vergelyk met die manier waarop die retoriek van die Brief aan Filemon in ons tyd geïnterpreteer word, is die opvallendste verskil die groot rol wat die kategorieë van eer en skande in JC se interpretasie speel. Dit is wel waar dat hierdie kategorieë nou en dan opduik in die moderne interpretasie van die Brief aan Filemon (bv. Church 1978:27; Lampe 2010:70), maar dit word nooit op so 'n konsekwente manier gebruik soos wat JC dit doen nie. Dat hierdie begrippe ' $n$ baie belangrike rol in JC se omgang met Bybelse tekste gespeel het, is reeds deur Stander en De Wet aangetoon. Stander (2003:899-913) het aangetoon watter belangrike rol dié kategorieë in JC se interpretasie van die Evangelie van Johannes speel, en De Wet (2010:317-331) het veral gefokus op die belangrike rol wat die begrip 'eer' speel in JC se houding teenoor slawe en rykdom in sy tyd. Uit die oorsig in die vorige afdeling het dit geblyk dat JC dié kategorieë nie net gebruik om Filemon verstaanbaar te maak vir die gelowiges in sy eie tyd nie, maar dat hy ook die manier waarop Paulus die brief gebruik om Filemon te oorreed, tot 'n groot mate in terme van hierdie kategorieë verstaan. Dit het op verskeie maniere duidelik geword. Ek lig slegs enkele momente uit: Wanneer die retoriese situasie van die brief beskryf word, is moderne uitleggers geneig om dit vanuit die perspektief van Paulus en Onesimus te beskryf, (bv. Church 1978:20; Fitzmyer 2000:23; Wilson 1992:112). In sy interpretasie begin JC egter by Filemon. Uit die bespreking in die vorige afdeling, het dit byvoorbeeld geblyk dat dit sy vertrekpunt is dat Filemon 'n eerbare man was, en dat sy heel eerste $\sin$ in Homilie 1 eksplisiet die aandag daarop vestig dat die brief namens 'n slaaf aan 'n eienaar gerig is. Hy beklemtoon ook gereeld dat Filemon met reg woedend was oor die skade wat hy deur Onesimus gely het. Die groot rol wat die kategorieë van eer en skande in JC se begrip van Paulus se retoriese strategie speel, blyk ook uit die feit dat hy gereeld gebruik maak van die gedagte dat Paulus iets doen om Filemon te verleë te maak of om hom te beskaam. Hierdie begrip veronderstel dat Paulus Filemon se meerdere is en dat Filemon se eie eer op die spel is in die manier waarop hy teenoor Paulus optree. Die belangrike rol wat hierdie kategorieë van eer en skande speel, kan ook gesien word in die manier waarop die verandering in Onesimus beskryf word. Hy was aanvanklik geheel en al eerloos. Ons het byvoorbeeld gesien hoe JC (anders as sommige moderne uitleggers, bv. Lampe 1998:206) glad nie eens die moontlikheid oorweeg dat Onesimus 'n wettige rede gehad het om te vlug nie; sy optrede word deurgaans in kras terme beskryf. Die verandering wat ná sy bekering plaasvind, word eweneens deur JC vertolk as 'n grootskaalse verwerwing van eer: Hy word niks minder nie as Paulus se 'seun' en deel gevolglik in Paulus se eer, en moet ook as sodanig deur Filemon ontvang word. Ek gaan nie verder uitbrei op al die voorbeelde hiervan in JC se uitleg van die brief nie. Die belangrike punt is dat hierdie perspektief op Paulus se retoriese strategie in die Brief aan Filemon grootliks ontbreek in eietydse interpretasies van die retoriek in die brief, en dat dit met vrug geïnkorporeer en bruikbaar gemaak kan word. 'n Tweede belangrike insig is dat JC dikwels verder gaan as moderne interpreteerders van die brief deurdat hy 'n eksplisiete, retoriese doelwit lees in dele van die brief waarin dit deesdae nie gesien of selfs eens oorweeg word nie. 'n Mens kan nie sonder meer aanvaar dat JC elke keer reg is wanneer hy dit doen nie, maar dit is tog belangrik dat hierdie insigte van JC deel sal word van die gesprek oor die interpretasie van die Brief aan Filemon, en krities geweeg moet word. Ek lig enkele voorbeelde van sulke gevalle uit: Volgens JC is die woord 'genade' in die seëngroet (v. 3) bedoel om Filemon te herinner aan sy eie sonde en aan die feit dat hy deur genade gered is, en word hy daardeur opgeroep om die voorbeeld van sy 'Eienaar' na te volg. Verder stel JC dit dat Paulus in verse 4-6 doelbewus eers op ander sake konsentreer en nie dadelik sy versoek rig nie, omdat hy die indruk probeer vermy dat Onesimus die enigste rede is hoekom hy die brief skryf. Wat vers 6 betref, lees JC die uitdrukking 'gemeenskap van jou geloof' as 'n retoriese strategie om Filemon verleë te maak iets wat, sover ek kon vasstel, nooit deur moderne uitleggers gedoen word nie. Die begrip 'vrymoedigheid' in vers 8 word intensief deur moderne uitleggers van die Brief aan Filemon bespreek, maar JC beklemtoon 'n moment wat gewoonlik nie genoem word nie, en dit is dat hy dié begrip lees vanuit die moontlike effek wat dit op Filemon sou hê: Deur dié begrip teenoor Filemon te gebruik impliseer Paulus dat Filemon 'n 'groot man' is, want dit is Filemon se vroeëre optrede wat gemaak het dat Paulus soveel vrymoedigheid het. Met ander woorde, die verwysing na vrymoedigheid funksioneer retories gesproke as 'n kompliment. Wat vers 11 betref (waar Paulus die stelling maak dat Onesimus nou vir homself en vir Filemon bruikbaar is), lees JC a minori ad maior-argument agter Paulus se 'vir my (bruikbaar)': As Filemon bruikbaar kon wees vir Paulus wat soveel presiesheid ten opsigte van deugdelikheid verwag, sal hy des te meer bruikbaar vir Filemon wees. 'n Laaste voorbeeld: Soos JC interpreteer moderne uitleggers ook die persone wat Paulus in verse 2324 vermeld as 'n vorm van emosionele druk wat op Filemon uitgeoefen word (bv. Fitzmyer 2000:125 \& Weima 2010:59). JC gaan egter verder deurdat hy die feit dat Epafras eerste genoem word, baie eksplisiet interpreteer: Hy word eerste genoem omdat hy, soos Filemon, van Kolosse afkomstig was, en dié aspek gebruik word om druk op Filemon uit te oefen: Indien Epafras as Filemon se medeburger bereid is om soveel saam met Paulus te ly, kan Filemon nie weier om vir Paulus 'n guns te doen nie.

Derdens is daar gevalle waar JC se interpretasie van Filemon heeltemal verskil van die manier waarop dit deesdae gedoen word. In sommige gevalle is sy interpretasie ooglopend verkeerd, maar daar is ander gevalle waar sy interpretasie verdere oorweging verdien. Een voorbeeld om eersgenoemde te illustreer: JC het die verwysing na die kerk in Filemon se huis (v. 2) heeltemal verkeerd verstaan, naamlik as dat dit sou beteken het dat die hele huishouding die kerk uitgemaak het en dat almal in die huis (ook die slawe) gelowiges was. Ek bied ook twee illustrasies van waar JC die teks anders lees, en dit oorweeg behoort te word: In sy interpretasie van die begrip 'in boeie verwek' in vers 10 gaan JC verder 
as moderne interpreteerders deurdat hy daarop wys dat die omstandighede waartydens Onesimus 'verwek' is, naamlik toe Paulus besig was om eervol te ly vir Christus, tot gevolg het dat Onesimus 'n eervolle mens is. JC se interpretasie van vers 19 (waar Paulus met sy eie hand bevestig dat Filemon enigiets wat Onesimus verskuldig is, op sy naam kan sit) kan as tweede voorbeeld dien. Moderne uitleggers interpreteer dit gewoonlik as dat Paulus dit doodernstig bedoel (bv. Barth \& Blanke 2000:482-484; Wolter 1993:276), maar JC interpreteer dit as 'n gemoedelike opmerking. Daar was wel enkele uitleggers in 'n vorige era wat vers 19 as 'n lighartige opmerking geïnterpreteer het (Bieder 1944:46), maar hierdie opsie het heeltemal uit die moderne uitlegtradisie verdwyn. Dalk verdien JC se opmerking verdere oorweging?

\section{Samevatting}

Die doel van hierdie artikel was om ondersoek in te stel of bestaande retoriese analises van die Brief aan Filemon sou kon baat vind by die manier waarop JC die brief in sy homilieë uitgelê het. Ek vertrou dat ek aangetoon het dat JC se interpretasie van retoriese aspekte in die brief nie net baie interessant is nie, maar dat die huidige uitlegtradisie wesenlik daardeur kan baat. Dit is wel so dat JC se uitleg nie noodwendig korrek of die beste uitleg van die teks is nie, maar die feit dat die samelewing, waarbinne hy geleef het, tot 'n groter mate as ons s'n oorvleuel met dié een waarbinne Paulus geleef het, beteken dalk dat hy aspekte in die teks raaklees wat ons doodgewoon miskyk. Die feit dat hy self opleiding in retoriek van hoogstaande aard gehad het, beteken ook dat ons deur die lees van sy interpretasie 'n goeie aanvoeling kan kry van die manier waarop Paulus se Brief aan Filemon in sulke kringe geïnterpreteer sou kon word. Kortom, dit is die moeite werd vir moderne uitleggers van die teks om JC as 'n waardige gespreksgenoot te hanteer wanneer hulle die retoriese fasette probeer begryp. 'n Laaste opmerking: Daar is nog verskeie ander interpretasies van Filemon deur ander kerkvaders beskikbaar. Soortgelyke ondersoeke kan dalk eweneens bruikbare resultate oplewer.

\section{Erkenning}

Die finansiële ondersteuning van die Nasionale Navorsingstigting (NNS) van Suid-Afrika vir die navorsingsprojek waarvan hierdie studie deel uitmaak, word erken.

\section{Mededingende belange}

Die outeur verklaar hiermee dat hy geen finansiële of persoonlike verbintenis het met enige party wat hom nadelig of voordelig kon beïnvloed het in die skryf van hierdie artikel nie.

\section{Literatuurverwysings}

Barth, M. \& Blanke, H., 2000, The Letter to Philemon. A new translation with notes and commentary, William B. Eerdmans, Grand Rapids, MI. (ECC).

Bieder, W., 1944, Der Philemonbrief, Zwingli-Verlag, Zürich.

Callahan, A.D., 1993, 'Paul's Epistle to Philemon: Toward an alternative argumentum', HThR 86, 357-376.

Callahan, A.D., 1995, 'John Chrysostom on Philemon: A response to Margaret M. Mitchell', Harvard Theological Review 88(1), 149-156. http://dx.doi.org/10.1017/ S0017816000030418

Church, F.F., 1978, 'Rhetorical structure and design in Paul's Letter to Philemon', Harvard Theological Review 71(1/2), 17- 33. http://dx.doi.org/10.1017/ S0017816000025554

De Wet, C., 2010, 'Honour discourse in John Chrysostom's exegesis of the Letter to Philemon', in D.F. Tolmie \& A. Friedl (eds.), Philemon in perspective. Interpreting a Pauline letter, pp. 317-331, De Gruyter, Berlyn/New York. (BZNW 169).

Decock, P.B., 2010, 'The reception of the Letter to Philemon in the early church: Origen, Jerome, Chrysostom and Augustine', in D.F. Tolmie \& A. Friedl (eds.), Philemon in perspective: Interpreting a Pauline letter, pp. 273-288, De Gruyter, Berlyn/New York. (BZNW 169)

Domeris, W.R., 1993, 'Honour and shame in the New Testament', Neotestamentica 27, 283-297.

Drobner, H.R., 2008, The fathers of the church. A comprehensive introduction (translated by Siegfried. S. Schatzmann with bibliographies updated and expanded for the English edition by William Harmless, S.J., and Hubertus R. Drobner), Hendrickson, Peabody, MA.

Elliott, S.S., 2011, “"Thanks, but no thanks": Tact, persuasion, and the negotiation of power in Paul's Letter to Philemon', New Testament Studies 57(1), 51-64. http://dx.doi.org/10.1017/S0028688510000238

Fitzmyer, J.A., 2000, The Letter to Philemon. A new translation with introduction and commentary, Doubleday, New York, NY/London. (AB 34C).

John Chrysostom, 1862, In Phlm. hom, Patrologia Graeca 62.701-720.

Kelly, J.N.D., 1995, Golden mouth: The story of John Chrysostom - ascetic, preacher, bishop, Cornell University Press, Ithaca, NY.

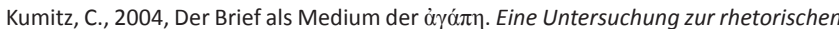
und epistolographischen Gestalt des Philemonbriefes, Peter Lang, Frankfurt am Main/Berlyn. (EHS 787).

Lampe, G.W.H., 1961, A patristic Greek lexicon, Clarendon Press, Oxford.

Lampe, P., 1998, Der Brief an Philemon. Übersetzt und erklärt von Peter Lampe, Vandenhoeck \& Ruprecht, Göttingen. (NTD).

Lampe, P., 2010, 'Affects and emotions in the rhetoric of Paul's Letter to Philemon: A rhetorical-psychological interpretation', in D.F. Tolmie \& A. Friedl (eds.), Philemon in perspective. Interpreting a Pauline letter, pp. 61-78, De Gruyter, Berlyn/New York, NY. (BZNW 169).

Mitchell, M.M., 1995, 'John Chrysostom on Philemon: A second look', HThR 88, 135-148.

Mitchell, M.M., 2002, The heavenly trumpet: John Chrysostom and the art of Pauline interpretation, Westminster John Knox Press, Louisville, KY.

Nestle-Aland, 2012, Novum Testamentum Graeca, based on the work of Eberhard and Erwin Nestle, Barbara and Kurt Aland, Johannes Karavidopoulos, Carlo M. Martin \& Bruce M. Metzger (ed.), 28th rev. edn., Deutsche Bibelgesellschaft, Münster.

Quasten, J., 1960, Patrology Vol. III, Spectrum/Newman, Utrecht/Westminster, MD.

Russell, D.M., 1998, 'The strategy of a first-century appeals letter: A discourse reading of Paul's Epistle to Philemon', Journal of Translation and Textlinguistics 11, 1-25.

Snyman, A.H., 2009, 'Persuasion in Paul's Letter to Philemon', Acta Patristica et Byzantina 20, 178-193.

Stander, H.F., 2003, 'Honour and shame as key concepts in Chrysostom's exegesis of the Gospel of John', HTS Teologiese Studies/Theological Studies 59(3), 899-913. http://dx.doi.org/10.4102/hts.v59i3.679

Wansink, C.S., 1996, Chained in Christ: The experience and rhetoric of Paul's imprisonments, Sheffield Academic Press, Sheffield. (JSNT.S 130).

Weima, J.A.D., 2010, 'Paul's persuasive prose: An epistolary analysis of the Letter to Philemon', in D.F. Tolmie \& A. Friedl (red.), Philemon in perspective. Interpreting a Pauline letter, pp. 29-60, De Gruyter, Berlyn/New York. (BZNW 169).

Wendland, E., 2010, “'You will do even more than I say": On the rhetorical function of stylistic form in the Letter to Philemon', in D.F. Tolmie \& A. Friedl (eds.), Philemon in perspective. Interpreting a Pauline letter, pp. 79-112, De Gruyter, Berlyn/New York, NY. (BZNW 169.)

Wilson, A., 1992, 'The pragmatics of politeness and Pauline epistolography: A case study of the Letter to Philemon', Journal for the Study of the New Testament 48, 107-119.

Wolter, M., 1993, Der Brief an die Kolosser. Der Brief an Philemon, Gerd Mohn, Gütersloh. (ÖTBK 12). 